\title{
DETERMINAN NON-PERFORMING FINANCING PADA BANK UMUM SYARIAH DI INDONESIA
}

\author{
Indrajaya \\ Program Studi Kajian Timur Tengah dan Islam \\ Universitas Indonesia \\ Email : indrajaya.ui@gmail.com
}

\section{ARTICLE HISTORY}

Received:

9 May 2019

Accepted:

28 June 2019

Online available:

30 June 2019

Keywords:

Non-Performing

Financing, Non-

Performing Loan,

Islamic

Commercial Bank, Indonesia.

\begin{abstract}
The accumulation of non performing financing in economic activities financed by banks can cause problems with the continuity of the bank's operations, if that exceeds certain limits will have potential to stop the bank's activities. This study aims to analyze the influence of bank's internal variables like internal and bank external variables consisting of exchange rates, inflation and GDP (GDP) against non-Performing Financing (NPF) of Islamic Commercial Banks in Indonesia. The data used are monthly industrial time series of Sharia Commercial Banks (BUS) for the period June 2014 to December 2018 sourced from the Islamic Banking Statistics of the Financial Services Authority, the Central Bureau of Statistics (Badan Pusat Statistik) and Bank Indonesia and analyzed using multiple regression methods. The research implications explain the relationship between the internal variables of the bank company and macroeconomic variables on the NPF of Islamic banks in Indonesia so that they can be used as input for the relevant authorities in making policies to suppress NPF at a low level. The variables used can provide an overview of the role of the implementation of sharia public bank governance and existing macroeconomic conditions so that it can produce policies and provisions in the field of sharia banking that are effective and on target. The results showed that the CAR variable had a significant effect on NPF with negative influence. Whereas FDR, BOPO, exchange rate, inflation and GDP have no influence on NPF BUS in Indonesia
\end{abstract}


Kata Kunci:

Non-Performing

Financing, Non-

Performing Loan,

Bank Umum

Syariah, Indonesia.

\section{ABSTRAK}

Akumulasi pembiayaan macet dalam kegiatan ekonomi yang dibiayai oleh bank dapat menimbulkan pemasalahan terhadap kelangsungan operasional bank, yang apabila sudah melampaui batasan tertentu berpotensi menghentikan kegiatan bank. Penelitian ini bertujuan untuk menganalisa pengaruh variabel internal bank dan variabel eksternal yang terdiri dari nilai tukar, inflasi dan PDB (GDP) terhadap pembiayaan macet atau NonPerforming Financing (NPF) Bank Umum Syariah di Indonesia. Data yang digunakan adalah data industri Bank Umum Syariah (BUS) time series bulanan periode Juni 2014 sampai dengan Desember 2018 yang bersumber dari Statistik Perbankan Syariah Otoritas Jasa Keuangan, Biro Pusat Statistik dan Bank Indonesia serta dianalisis menggunakan metode regresi berganda. Implikasi penelitian menjelaskan hubungan antara variabel-variabel mikro perusahaan dan variabel makroekonomi terhadap NPF bank umum syariah di Indonesia sehingga dapat digunakan sebagai salah satu masukan bagi otoritas terkait dalam membuat kebijakan untuk menekan NPF pada level rendah. Variabel yang digunakan dapat memberikan gambaran peranan implementasi governance bank umum syariah dan kondisi makroekonomi yang ada sehingga dapat menghasilkan kebijakan dan ketentuan di bidang perbankan syariah yang efektif dan tepat sasaran. Hasil penelitian menunjukkan bahwa variabel CAR pengaruh signifikan terhadap NPF dengan pengaruh negarif. Sedangkan FDR, BOPO, nilai tukar, inflasi dan PDB tidak memiliki pengaruh terhadap NPF BUS di Indonesia.

\section{PENDAHULUAN}

Dalam sistem keuangan islam, hasil dari investasi dan pembiayaan yang dilakukan bank di sektor riil menentukan pembagian keuntungan di sektor moneter. Sektor moneter memiliki ketergantungan kuat akan sektor riil. Jika investasi dan produksi di sektor riil berjalan dengan lancar, maka return pada sektor moneter akan meningkat. Idealnya pemanfaatan sumber daya ekonomi dapat dilakukan secara langsung dari pihak yang memiliki dana/ berinvestasi (sahibul maal) langsung kepada sektor produksi. Namun dalam perkembangannya ketidakmerataan distribusi kekayaan yang ada di suatu negara antara si pemilik dana dengan si pemilik keahlian dalam melakukan produksi 
harus dapat dijembatani oleh adanya suatu sistem ekonomi yang dapat menfasilitasi perdistribusiannya. Disitulah masuk peran bank untuk dapat menjembatani ketimpangan yang terjadi, khususnya bank syariah yang merupakan industri yang paling berkembang dengan aset paling besar dalam perekonomian islam di Indonesia.

Seiring dengan berjalannya waktu, perbankan syariah di Indonesia telah berkembang dengan pesat. Data Statistik Perbankan Syariah yang diterbitkan oleh Otoritas Jasa Keuangan (OJK) menyebutkan saat ini telah terdapat 13 Bank Umum Syariah (BUS) dan 21 Unit Usaha Syariah (UUS) dari Bank Umum Konvensional yang tergabung dalam industri perbankan syariah. Dari industri tersebut telah diperoleh pengumpulan dana pihak ketiga (DPK) yang semakin tahun tercatat selalu mengalami peningkatan terhitung pada bulan Desember 2018 sebesar Rp371,83 triliun. Jumlah ini meningkat 11,03\% dibandingkan tahun 2017 dan 60,84\% dibandingkan 3 tahun sebelumnya pada 2015. Sedangkan total berbagai jenis pembiayaan yang berhasil disalurkan oleh perbankan syariah mencapai Rp321,31 triliun yang meningkat $12,02 \%$ dibandingkan tahun 2017 dan 50,15\% dibandingkan 3 tahun terakhir. Dari sejumlah indikator tersebut di atas, BUS memiliki pangsa terbesar dari 69,28\% dari total DPK dan $63,11 \%$ dari total pembiayaan industri perbankan syariah.

Layaknya suatu sistem, maka sistem keuangan yang dibangun atas dasar landasan islam ini juga tak luput dari masalah. Sebagai lembaga intermediasi antara unit surplus (pemilik dana) dengan unit defisit (yang membutuhkan pembiayaan), komposisi dana bank berasal dari masyarakat sehingga secara moral mereka harus menyalurkan kembali kepada masyarakat dalam bentuk pembiayaan. Dalam prakteknya, jumlah pembiayaan yang disalurkan kepada masyarakat tidak selalu berkategori sehat, terdapat pula pembiayaan yang berkualitas buruk atau bermasalah yang biasa disebut sebagai Non-Performing Financing (NPF) yang merupakan rasio pembiayaan bermasalah terhadap total pembiayaan yang disalurkan. Dampak dari permasalahan NPF ini apabila telah melampaui suatu batasan tertentu maka akan berakibat pada terganggunya operasional yang dapat berujung pada penghentian kegiatan bank syariah. Oleh sebab itu maka, perlu dikuantifisir faktor-faktor yang mempengaruhi terjadinya pembiayaan bermasalah, khususnya pada Bank Umum Syariah di Indonesia.

\section{LANDASAN TEORI}

Non-Performing Financing (NPF) merupakan rasio pembiayaan yang bermasalah bagi suatu bank. Pembiayaan bermasalah yang meningkat akan mengakibatkan terjadinya penurunan tingkat keuntungan bagi bank. Dampaknya adalah apabila profitabilitas menurun, maka kemampuan bank untuk melakukan ekspansi pembiayaan berkurang sehingga laju pembiayaan menjadi turun. Risiko pembiayaan yang diterima 
bank merupakan salah satu risiko usaha bank, yang diakibatkan dari tidak dilunasinya kembali pinjaman yang diberikan atau investasi yang sedang dilakukan oleh pihak bank (Muhammad, 2005:359).

NPF sangat berpengaruh terhadap pengendalian biaya dan kebijakan pembiayaan yang akan dilakukan oleh bank. NPF yang besar dan berlangsung terus menerus akan dapat mengurangi modal bank sehingga akan membatasi ruang gerak bank dalam melakukan kegiatan operasionalnya, khususnya terkait ekspansi usaha. Perkembangan NPF pada industri perbankan syariah dipengaruhi oleh beberapa variabel, baik yang berasal dari internal perusahaan maupun eksternal perusahaan. Faktor internal umumnya berasal dari mekanismecorporate governance perusahaan, sedangkan faktor eksternal umumnya dipengaruhi indikator makroekonomi. Berbagai faktor internal dan eksternal tersebut akan diakomodasi dalam penelitian untuk melihat perilaku yang secara signifikan mempengaruhi NPF perbankan syariah.

Capital Adequacy Ratio (CAR) adalah rasio yang digunakan untuk mengukur kecukupan modal yang dimiliki bank untuk menunjang aktiva yang mengandung atau menghasilkan risiko, seperti halnya terhadap kredit/ pembiayaan yang diberikan (Dendawijaya, 2005:122). Besarnya CAR dapat mempengaruhi kemampuan bank dalam mengambil keputusan terkait risiko. Selanjutnya rasio Biaya Operasional terhadap Pendapatan Operasional (BOPO) adalah perbandingan antara biaya operasional dan pendapatan operasional. Semakin rendah tingkat rasio BOPO maka semakin baik kinerja manajemen bank karena lebih efisien dalam menggunakan sumber daya (Setiawan, 2009). Sedangkan Financing to Deposit Ratio (FDR) adalah istilah lain dari Loan to Deposit Ratio (LDR) yang digunakan untuk mengukur lembaga keuangan berbasis islam dan merupakan rasio perbandingan antara pembiayaan dan dana pihak ketiga (DPK). Semakin tinggi rasio FDR maka akan semakin berisiko buat bank, namun semakin rendah rasio FDR mengindikasikan bahwa fungsi intermediasi pada bank tidak berjalan dengan baik.

Ekonomi makro menganalisa keadaan seluruh kegiatan perekonomian. Ekonomi makro tidak membahas kegiatan yang dilakukan oleh seorang produsen, seorang konsumen atau seorang pemiliki faktor produksi, tetapi pada keseluruhan tindakan para konsumen, para pengusaha, pemerintah, lembaga-lembaga keuangan dan negaranegara lain serta bagaimana pengaruh tindakan tersebut terhadap perekonomian secara keseluruhan (Suyuthi, 1989:3). Adapun faktor makroekonomi yang digunakan dalam penelitian ini adalah inflasi, PDB/GDP dan nilai tukar rupiah terhadap dollar amerika.

Inflasi didefinisikan sebagai peningkatan harga secara menyeluruh dalam ekonomi yang dapat disebabkan oleh peningkatan jumlah uang beredar sehingga 
menyebabkan penurunan nilai uang (Mankiw, 2011:15). Sedangkan Bank Indonesia mendefinisikannya sebagai keadaan perekonomian yang ditandai oleh kenaikan harga secara cepat sehingga berdampak pada menurunnya daya beli, sering pula diikuti menurunnya tingkat tabungan dan atau investasi karena meningkatnya konsumsi masyarakat dan hanya sedikit untuk tabungan jangka panjang. Sedangkan nilai tukar adalah rasio dari dua mata uang yang diperdagangkan yang merupakan harga mata uang suatu negara terhadap mata uang negara lain (Case et all, 2010:358). Nilai tukar dipengaruhi oleh beberapa faktor, seperti tingkat suku bunga dalam negeri, tingkat inflasi, dan intervensi bank sentral terhadap pasar uang jika diperlukan sehingga senantiasa berubah. Dalam penelitian ini nilai tukar yang digunakan adalah nilai tukar spot mata uang rupiah terhadap mata uang dollar Amerika Serikat. Untuk variabel makroekonomi berikutnya, Produk Domestik Bruto (Gross Domestik Product/ GDP) didefinisikan total pendapatan dari setiap pelaku ekonomi yang merepresentasikan total belanja barang dan jasa dalam ekonomi (Mishkin, 2012:19). Sedangkan Badan Pusat Statistik mendefinisikan sebagai jumlah nilai tambah yang dihasilkan oleh seluruh unit usaha dalam suatu negara tertentu, atau merupakan jumlah nilai barang dan jasa akhir yang dihasilkan oleh seluruh unit ekonomi.

Nikola Radivojevic dan Jelena Jovovic dalam sebuah penelitian berjudul examining of determinants of non-performing loans yang meneliti faktor-faktor determinan terhadap terjadinya NPL di 25 negara menyimpulkan bahwa GDP mempunyai pengaruh determinasi yang krusial terhadap rasio NPL di beberapa negara berkembang dengan arah korelasi negatif (Radivojevic et al, 2017). Hal ini berseberangan dengan hasil penelitian yang dilakukan oleh B. Tabak dengan judul the stabilityconcentration relationship in the Brazilian banking sistem yang mengindikasikan bahwa terdapat hubungan signifikan berkorelasi positif antara GDP dan NPL (Tabak et al, 2001).

Dalam penelitian yang berjudul analisis faktor-faktor yng mempengaruhi terjadinya non-performing loan (NPL) pada bank umum komersial, Hermawan Soebagio menyatakan bahwa faktor makro (kurs, inflasi dan GDP) dan faktor mikro (CAR, Loan to Deposit Ratio, Tingkat Bunga Pinjaman Bank dan Kualitas Aktiva Produktif) memberikan pengaruh kepada terjadinya NPL (Soebagio, 2005:117-121). Namun penelitian lain terkait NPF pada BPRS di Indonesia yang dilakukan oleh Irman Firmansyah yang berjudul determinant of non-performing loan: the case of Islamic bank in indonesia yang menyimpulkan bahwa GDP memberikan pengaruh terhadap NPF, sedangkan ukuran bank dan BOPO tidak memberikan pengaruh terhadap tingkat NPF (Firmansyah, 2014).

\section{METODE PENELITIAN}

\section{Rancangan Penelitian}


Jenis penelitian yang digunakan adalah penelitian korelasional dengan pengujian hipotesis yang bertujuan untuk menguji dan menganalisis pengaruh dari variable independen dalam hal ini CAR, FDR, BOPO, Kurs, Inflasi dan PDB terhadap variable dependen yaitu NPF.

\section{Variabel dan pengukurannya}

Variabel yang digunakan dalam penelitian ini terdiri dari variabel dependen yaitu NPF dan variabel independent yaitu sebanyak 6 variabel yaitu CAR, Pengukuran dari masiang-masing variabel dapat dijelaskan pada tabel berikut:

Tabel 1

Variabel dan Pengukuran

\begin{tabular}{|c|c|c|}
\hline Nama Variabel & Pengukuran & Skala \\
\hline $\begin{array}{l}\text { Non Perforrming } \\
\text { Financing (NPF) }\end{array}$ & $\mathrm{NPF}=\frac{\text { Pembiayaan kolektibilitas Macet }}{\text { Total Pembiayaan }}$ & Rasio \\
\hline $\begin{array}{l}\text { Financing Debt Ratio } \\
\text { (FDR) }\end{array}$ & $\mathrm{FDR}=\frac{\text { Pembiay aan Bank }}{\text { Total Dana Pihak Ketiga }}$ & Rasio \\
\hline $\begin{array}{l}\text { Capital Adequacy } \\
\text { Ratio (CAR) }\end{array}$ & $\mathrm{CAR}=\frac{\text { Modal }}{\text { Aktiva Tetap Menurut Resiko }}$ & Rasio \\
\hline $\begin{array}{l}\text { Beban Operasional } \\
\text { Terhadap Pendapatan } \\
\text { Operasional (BOPO) }\end{array}$ & $\mathrm{BOPO}=\frac{\text { Beban Operasional }}{\text { Pendapatan Operasional }}$ & Rasio \\
\hline Kurs & $\begin{array}{l}\text { Perbandingan nilai mata uang rupiah terhadap } \\
\text { dollar yang dinyatakan dengan } \mathrm{Rp} / \$\end{array}$ & Rasio \\
\hline Inflasi & $\begin{array}{l}\text { Akumulasi inflasi bulanan selama satu tahun } \\
\text { dengan tahun dasar } 2012 \text { yang dinyatakan dari } \\
\text { bulan satu ke bulan berikutnya dengan formulasi } \\
\text { Inflasi }=\sum_{\mathrm{t}=1}^{12} \frac{\mathrm{IHK}_{\mathrm{t}}-\mathrm{IHK}_{\mathrm{t}-1}}{\mathrm{IHK}_{\mathrm{t}-1}} \times 100 \%\end{array}$ & Rasio \\
\hline $\begin{array}{l}\text { Tingkat Kegiatan } \\
\text { Ekonomi }\end{array}$ & $\begin{array}{l}\text { Produk Domestik Bruto Riil dengan tahun dasar } \\
\text { tahun } 2010 \text { data kuartalan }\end{array}$ & Rasio \\
\hline
\end{tabular}

Sumber : Data Penulis

Data dan Sampel 
Data yang digunakan dalam penelitian ini merupakan data time series (data berkala) industri BUS untuk masing-masing variabel penelitian dengan periode waktu bulanan mulai dari Juni 2014 (2014:06) sampai dengan Desember 2018 (2018:12). Data NPF, FDR, CAR dan BOPO diperoleh dari Statistik Perbankan Syariah yang dipublikasikan oleh Otoritas Jasa Keuangan (OJK), sedangkan data inflasi dan PDB diperoleh dari Badan Pusat Statistik (BPS), serta nilai tukar rupiah (IDR) terhadap dollar Amerika Serikat (USD) menggunakan nilai tengah kurs IDR/USD yang diperoleh dari Bank Indonesia

\section{Metode Analisis}

Untuk menjawab permasalahan penelitian ini digunakan analisis regresi berganda yang dinyatakan dengan persamaan:

$\mathrm{NPF}_{\mathrm{t}}=\beta_{0}+\beta_{1} \mathrm{CAR}_{\mathrm{t}}+\beta_{2} \mathrm{FDR}_{\mathrm{t}}+\beta_{3} \mathrm{BOPO}_{\mathrm{t}}+\beta_{4}$ Kurs $_{\mathrm{t}}+\beta_{5}$ Inflasi $_{\mathrm{t}}+\beta_{6} \mathrm{PDB}_{\mathrm{t}}+\varepsilon$

Analisis model regresi dilakukan dengan tahapan sebagai berikut:

\section{Uji Asumsi Klasik}

Dilakukan untuk menghasilkan koefisien estimasi yang dihasilkan dari model regresi bersifat BLUES (Best Linier, Unbiased Estimator)

Tabel 2

Uji Asumsi Klasik

\begin{tabular}{|c|c|c|}
\hline Uji & Hipotesis & Pengambilan Keputusan \\
\hline $\begin{array}{l}\text { Normalitas } \\
\text { (Jarque Berra) }\end{array}$ & $\begin{array}{l}\text { Ho: dist. error normal } \\
\text { Ha: dist. Error tidak normal }\end{array}$ & $\begin{array}{l}\text { Prob. }<0,05 \text { maka } \mathrm{H}_{0} \\
\text { ditolak } \\
\text { Prob. } \geq 0,05 \text { maka } \mathrm{H}_{0} \\
\text { diterima }\end{array}$ \\
\hline $\begin{array}{l}\text { Multikolinearitas } \\
\text { (VIF) }\end{array}$ & $\begin{array}{l}\text { Ho: tidak terdapat } \\
\text { multikolinearitas } \\
\text { Ha: terdapat multikolinearitas }\end{array}$ & $\begin{array}{l}\text { VIF } \leq 10 \text { maka } \mathrm{H}_{0} \text { diterima } \\
\text { VIF }>10 \text { maka } \mathrm{H}_{0} \text { ditolak }\end{array}$ \\
\hline $\begin{array}{l}\text { Autokorelasi } \\
\text { (LM test) }\end{array}$ & $\begin{array}{l}\text { Ho: tidak terdapat autokorelasi } \\
\text { Ha: terdapat autokorelasi }\end{array}$ & $\begin{array}{l}\text { Prob. dari Obs* } R^{2}<0,05 \\
\text { maka Ho ditolak } \\
\text { Prob. dari Obs* } R^{2} \geq 0,05 \\
\text { maka Ho diterima }\end{array}$ \\
\hline $\begin{array}{l}\text { Heteroskedastisitas } \\
\text { (White test) }\end{array}$ & $\begin{array}{l}\text { Ho: tidak terdapat autokorelasi } \\
\text { Ha: terdapat autokorelasi }\end{array}$ & $\begin{array}{l}\text { Prob. dari Obs* } R^{2}<0,05 \\
\text { maka Ho ditolak } \\
\text { Prob. dari Obs* } R^{2} \geq 0,05 \\
\text { maka Ho diterima }\end{array}$ \\
\hline
\end{tabular}

Sumber : Penulis

\section{Uji Hipotesis Teori}


Tabel 3

Uji Hipotesis Teori

\begin{tabular}{|c|c|c|}
\hline Uji & Hipotesis & Pengambilan Keputusan \\
\hline $\begin{array}{l}\text { Koefisien } \\
\text { Determinasi }\left(\mathrm{R}^{2}\right)\end{array}$ & $\begin{array}{l}\text { Untuk menjelaskan seberapa } \\
\text { besar variasi dari variabel } \\
\text { independen mampu } \\
\text { menjelaskan variasi dari } \\
\text { variabael dependennya }\end{array}$ & $\begin{array}{l}\text { Semakin mendekati } 1 \text { maka } \\
\text { model semakin fit, dan } \\
\text { mendekati } 0 \text { maka model } \\
\text { semakin tidak fit }\end{array}$ \\
\hline $\begin{array}{l}\text { Global } \\
\text { (Uji F) }\end{array}$ & $\begin{array}{l}\text { Ho: Seluruh variabel } \\
\text { independent tidak } \\
\text { mempengaruhi variabel } \\
\text { dependen } \\
\text { Ha: Paling sedikit terdapat } 1 \\
\text { variabel independen yang } \\
\text { berpengaruh terhadap variabel } \\
\text { dependen }\end{array}$ & $\begin{array}{l}\text { Prob. dari } F<0,05 \text { maka Ho } \\
\text { ditolak } \\
\text { Prob dari } F \geq 0,05 \text { maka Ho } \\
\text { diterima }\end{array}$ \\
\hline $\begin{array}{l}\text { Global } \\
\text { (Uji t) }\end{array}$ & $\begin{array}{l}\text { Ho: Variabel independen tidak } \\
\text { mempengaruhi variabel } \\
\text { dependen } \\
\text { Ha: Variabel independen } \\
\text { mempengaruh variabel } \\
\text { dependen }\end{array}$ & $\begin{array}{l}\text { Prob. dari } t<0,05 \text { maka Ho } \\
\text { ditolak } \\
\text { Prob dari t } \geq 0,05 \text { maka Ho } \\
\text { diterima }\end{array}$ \\
\hline
\end{tabular}

Sumber : Penulis

\section{HASIL DAN PEMBAHASAN}

\section{Statistik Deskriptif}

Dari hasil pengolahan statistik deskriptif untuk setiap variabel penelitian dapat dilihat bahwa seluruh data dari masing-masing variabel penelitian berdistribusi normal seperti ditunjukkan dengan nilai probabilitas dari jarque berra yang seluruhnya berdistribusi normal artinya seluruh variabel yang digunakan memenuhi syarat kualitas data kuantitatif yaitu berdistribusi normal

Secara keseluruhan hasil statistik deskriptif variabel NPF industri BUS menghasilkan nilai rata-rata sebesar 3,061 dengan nilai standar deviasi sebesar 0,560 yang menunjukkan bahwa variasi data yang satu dengan yang lain tidak terlalu besar. Nilai tersebut masih berada dalam batasan kendali aman untuk BUS dalam mengelola risiko operasionalnya. Variabel CAR menghasilkan nilai rata-rata sebesar 16,458 dengan standar deviasi sebesar 2,068 menunjukkan volatilitas data variabel CAR relatif homogen. Namun secara umum, industri BUS memiliki kecukupan modal yang relatif memadai dalam rangka mengantisipasi risiko likuiditas dan solvabilitas. Variabel FDR menghasilkan nilai rata-rata sebesar 85,537 dan dengan nilai standar deviasi sebesar 
5,159 menunjukkan variasi data yang relatif kecil pada variabel FDR. Data tersebut menunjukkan bahwa kegiatan ekspansi pembiayaan yang dilakukan oleh BUS masih berada dalam kisaran yang diperbolehkan oleh ketentuan. Nilai rata-rata untuk variaael BOPO ditunjukkan dengan angka yang cukup signifikan yaitu sebesar 94,120. Dengan nilai standar deviasi sebesar 2,959 menunjukkan variasi BOPO BUS dari waktu ke waktu relatif stabil dan cenderung belum menunjukkan perbaikan ke arah yang efisiensi yang ditargetkan otoritas.

Rata-rata variabel kurs sebesar 13.413 dengan standar deviasi sebesar 747,66 menunjukkan variasi yang cukup besar pada pasar valuta asing di Indonesia dimana nilai rupiah relatif sensitif mengalami penurunan relatif terhadap mata uang dollar AS. Untuk Inflasi kumulatif perbulan menghasilkan nilai rata-rata sebesar 4,403 dengan nilai standar deviasi 1,503 menunjukkan adanya volatilias yang cukup besar pada sektor riil di Indonesia. Tingkat kegiatan ekonomi yang diproksi melalui PDB menghasilkan nilai ratarata sebesar 2.391.082. Dengan nilai standar deviasi sebesar 162.469 menunjukan variasi fluktuasi PDB Indonesia selama periode 2014:06 sampai dengan 2018:12 menunjukkan pola yang volatitasnya tidak terlalu tinggi. Untuk lebih jelasnya dapat dilihat pada tabel berikut.

Tabel 4

Statistik Deskriptif Variabel Penelitian

\begin{tabular}{llllllll}
\hline & NPF & CAR & FDR & BOPO & KURS & INFLASI & PDB \\
\hline Mean & 3.061 & 16.458 & 85.537 & 94.120 & 13413 & 4.403 & 2391082 \\
Maximum & 4.000 & 21.390 & 95.210 & 99.040 & 15227 & 8.360 & 2684186 \\
Minimum & 1.950 & 14.090 & 77.630 & 88.080 & 11591 & 2.790 & 2137386 \\
Std. Dev. & 0.560 & 2.068 & 5.159 & 2.959 & 747.66 & 1.503 & 162469 \\
Kurtosis & 1.725 & 3.090 & 1.731 & 2.204 & 3.475 & 2.714 & 1.910 \\
Jarque-Bera & 3.753 & 10.763 & 3.687 & 5.549 & 0.682 & 10.331 & 3.010 \\
Probability & 0.153 & 0.004 & 0.158 & 0.062 & 0.710 & 0.005 & 0.221 \\
Observations & 55 & 55 & 55 & 55 & 55 & 55 & 55
\end{tabular}

Sumber: data diolah

\section{Pengujian Hipotesis}


Sebelum dilakukan pengujian hipotesis terlebih dahulu dilakukan pengujian asumsi klasik. Model yang dihasilkan adalah model yang sudah direvisi yaitu setelah penyembuhan autokorelasi seperti ditunjukkan dalam lampiran. Hasil pengujian asumsi klasik dapat dijelaskan sebagai berikut:

a. Untuk normalitas diperoleh nilai prob dari jarque berra sebesar 0,255 >0,05 yang artinya Ho diterima sehingga dapat disimpulkan bahwa distribusi error normal atau dengan kata lain memenuhi persyaratan bahwa error harus berdistribusi normal.

b. Hasil pengujian multikolinearitas menunjukkan bahwa bahwa seluruh nilai VIF untuk 6 variabel independen < 10 sehingga Ho diterima dan dapat disimpulkan bahwa model yang dihasilkan terbebas dari masalah multikolinearitas.

c. Hasil pengujian autokorelasi ditunjukkan dengan nilai prob dari obs* $R^{2}$ sebesar 0,380 > 0,05 sehingga Ho diterima dan dapat disimpulkan bahwa pada model yang dihasilkan tidak terdapat autokorelasi.

d. Pengujian heteroskedastisitas dengan white test menghasilkan nilai prob dari obs* $R^{2}$ sebesar 0,512 yang artinya Ho diterima sehingga dapat disimpulkan bahwa pada model yang dihasilkan tidak terdapat heteroskedastisitas.

Selanjutnya, oleh karena asumsi yang disyaratkan terpenuhi maka pengujian hipotesis penelitian akan dilakukan. Hasil pengolahan untuk model NPF BUS pada industri perbankan syariah di Indonesia ditunjukkan dengan tabel 5.

Tabel 5

Pengujian Hipotesis Model Penelitian

\begin{tabular}{lllll}
\hline Deskripsi & Estimate & C.R. & P & VIF \\
\hline CAR berpengaruh negatif terhadap NPF & -0.0793 & -2.129 & 0.0386 & 6.355 \\
FDR berpengaruh positif terhadap NPF & 0.0054 & 0.379 & 0.7063 & 5.424 \\
BOPO berpengaruh positif terhadap NPF & -0.0438 & -2.143 & 0.0374 & 3.919 \\
Kurs berpengaruh positif terhadap NPF & $3.15 \mathrm{E}-05$ & 0.459 & 0.6480 & 2.613 \\
Inflasi berpengaruh positif terhadap NPF & 0.0102 & 0.318 & 0.7516 & 2.378 \\
PDB berpengaruh negatif terhadap NPF & $-9.51 \mathrm{E}-07$ & -1.571 & 0.1229 & 9.863 \\
\hline $\mathrm{R}^{2}$ adjusted & 0.842 & & & \\
\hline F ststistik & & & & \\
Prob & 41.459 & & & \\
\hline Jarque Berra & 0,000 & & & \\
Prob & 2,730 & & & \\
\hline
\end{tabular}




\begin{tabular}{ll}
\hline LM test & 0.767 \\
Prob & 0.380 \\
\hline White test & 34.0007 \\
Prob & 0,512 \\
\hline
\end{tabular}

Sumber : data diolah

Hari hasil pengolahan dapat dijelaskan sebagai berikut.

a. Koefisien determinasi yang dihasilkan sebesaer 0,842 nmenunjukkan bahwa variasi dari variabel indpenden yaitu CAR, FDR, BOPO, Kurs, Inflasi dan PDB mampu menjelaskan variasi dari variabel dependen yaitu NPF sebesaer $84,2 \%$ dan sisanya yaitu sebesar $25,8 \%$ adalah variasi dari variabel independent lain yang mempengaruhi NPF namun tidak diperhitungkan dalam model. Dengan demikian model NPF yang dihasilkan memiliki tingkat goodness of fit yang baik karena nilainya mendekati 1.

b. Pengujian global (uji F) menghasilkan nilai prob dari $F$ sebesar $0,000<0,05$ sehingga Ho ditolak dan Ha diterima. Oleh karena itu dapat disimpukan bahwa terbukti paling sedikit terdapat 1 variabel independen yang berpengaruh terhadap variabel dependennya yaitu dalam hal ini NPF.

c. Hasil pengujian parsial dapat dijelaskan sebagai berikut:

1) CAR terbukti berpengaruh signifikan negatif terhadap NPF seperti ditunjukkan dengan nilai koefisien estimasi regresi sebesar -0,0793 dengan nilai prob dari $t$ statistic sebesar 0,0386 >0,05 yang artinya Ho ditolak dan Ha diterima. Dampak dari peningkatan pembiayaan macet dapat mengakibatkan penurunan pendapatan BUS dan berakibat pada turunnya tingkat bagi hasil kepada nasabah pemilik dana. Lebih jauh, akumulasi jumlah pembiayaan macet yang relatif besar dapat mengurangi modal bank secara cepat dan meningkatkan potensi bank menjadi gagal beroperasi.

2) Hasil pengujian hipotesis untuk variabel FDR menunjukkan hipotesis yang menyatakan FDR berpengaruh positif terhadap NPF tidak terbukti karena nilai prob yang dihasilkan sebesar 0,7063 >0,05 sehingga Ho diterima dan dapat disimpulkan bahwa tidak terbukti adanya pengaruh positif dari FDR terhadap NPF

3) Pengaruh positif BOPO terhadap NPF berdasarkan hasil pengujian parsial menghasilkan kesimpulan tidak terbukti seperti ditunjukkan dengan nilai koefisien estimasi dari BOPO sebessar -0,0438 sehingga sekalipun menghasilkan nilai prob $0,0374<0,05$ tetapi tanda dari koefisien yang dihasilkan sudah berlawanan arah. 
4) Depresiasi, sekalipun terbukti menaikkan nilai NPF tetapi hipotesis yang menyatakan bahwa kurs berpengaruh positif terhadap NPF tidak terbukti karena nilai prob yang dihasilkan sebesar 0,6480 > 0,05 sehingga Ho diterima dan dapat disimpulkan bahwa tidak terbukti adanya pengaruh positif dari Kurs terhadap NPF.

5) Koefisien estimasi untuk inflasi sebesar 0,0102 menunjukkan bahwa inflasi berpengaruh positif terhadap NPF. Dengan nilai prob dari t sebesar 0,7516 $>0,05$ maka Ho diterima sehingga dapat disimpukan bahwa pengaruh positif dari inflasi terhadap NPF industri BUS di Indonesia tidak signifikan.

6) Hasil pengujian menunjukkan pengaruh negatif PDB terhadap NFP sekalipun koefisien yang dihasilkan menghasilkan nilai -9,51E-07 tetapi menghasilkan prob $0,1229>0,05$ sehingga Ho diterima yang artinya pengaruh negarif dari PDB terhadap NPF tidak signifikan.

\section{SIMPULAN}

Penelitian ini bertujuan untuk mengetahui variabel FDR, CAR, BOPO, Inflasi, Kurs dan PDB/GDP terhadap Non-Performing Financing (NPF) pada Bank Umum Syariah di Indonesia pada Juni 2014 sampai dengan Desember 2018. Berdasarkan hasil analisis yang dilakukan, maka dapat ditarik kesimpulan bahwa CAR memiliki pengaruh yang signifikan terhadap NPF dengan pengaruh negatif. Sedangkan FDR, BOPO, Inflasi, Kurs dan PDB tidak mempunyai pengaruh signifikan pada NPF. Terkait dengan dampak CAR pada NPF dan dalam rangka mendukung upaya memastikan bank memiliki kecukupan modal yang memadai untuk memenuhi seluruh kewajibannya serta menyerap potensi kerugian tidak terduga, maka penerapan aturan mengenai penambahan modal menjadi hal yang layak dipertimbangkan dalam rangka menguatkan ketahanan bank dalam mengantisipasi kerugian yang tidak terduga. Adanya kebijakan regulator untuk membentuk tambahan modal berupa capital conservation buffer, countercyclical buffer dan capital surcharge merupakan langkah kebijakan yang layak dijadikan perhatian. Ke depan kebijakan tersebut dapat menjadi salah satu alat regulator dalam mengarahkan perbankan nasional melalui variasi penentuan besaran komponen variabel-variabel kebijakan tersebut.

Peneliti selanjutnya diharapkan dapat mengembangkan model penelitian dengan range data yang lebih panjang dan penggunaan variabel yang lebih variatif sehingga dapat menangkap determinan lainnya yang dapat mempengaruhi NPF. 


\section{DAFTAR PUSTAKA}

Case, Karl E. Fair, Ray C. Oster, Sharon M. (2011). Principles of Macroeconomics. Tenth Edition. USA: Prentice Hall.

Dendawijaya, L. (2005). Manajemen Perbankan. Surabaya: Ghalia.

Firmansyah, I. (2014). Determinant of non performing loan: The case of islamic bank in indonesia. Buletin Ekonomi Moneter dan Perbankan, 17(2), 241-258.

Gujarati, D. N., \& Porter, D. C. (2006). Dasar-dasar ekonometrika. Jakarta: Erlangga.

Huda, N., Suprayogi, A., Aji, H., Andriyati, R., Aliyudin, A., Arbain, D. M., ... \& Harmoyo, T. (2012). Keuangan Publik Islami Pendekatan Teoritis dan Sejarah. Jakarta: Kencana.

Huda, Nurul et al. (2016). Ekonomi Makro Islam: Pendekatan Teoritis. Jakarta: Prenadamedia Group.

Mankiw, N. Gregory. (2011). Principles of Macroeconomics. 6th edition. USA: SouthWestern.

Mishkin, Frederic S. (2012). Macroeconomics: Policy and Practice. New York: AddisonWesley

Muhammad. (2005). Manajemen Bank Syariah. Yogyakarta: UPPAMP YKPN.

Otoritas Jasa Keuangan. (2018). Statistik Perbankan Syariah Desember 2017.

Radivojevic, N., \& Jovovic, J. (2017). Examining of determinants of non-performing loans. Prague Economic Papers, 26(3), 300-316.

Stiawan, A. (2009). Analisis Pengaruh Faktor Makroekonomi, Pangsa Pasar Dan Karakteristik Bank Terhadap Profitabilitas Bank Syariah (Studi Pada Bank Syariah Periode 2005-2008) (Doctoral dissertation, UNIVERSITAS DIPONEGORO).

Soebagio, H. (2005). Analisis Faktor-faktor yang Mempengaruhi Terjadinya Non Performing Loan (NPL) pada Bank Umum Komersial (Studi Empiris pada Sektor Perbankan di Indonesia) (Doctoral dissertation, PROGRAM PASCASARJANA UNIVERSITAS DIPONEGORO).

Suyuthi, M. Djamil. (1989). Pengantar Ekonomi Makro. Jakarta: P2LPTK Departemen Pendidikan dan Kebudayaan Republik Indonesia.

Zulifiah, F. (2014). PENGARUH INFLASI, BI RATE, CAPITAL ADEQUACY RATIO (CAR), NON PERFORMING FINANCE (NPF), BIAYA OPERASIONAL DANPENDAPATAN OPERASIONAL (BOPO) TERHADAP PROFITABILITAS BANK UMUM SYARIAHPERIODE 
Indrajaya | Jurnal Ekonomi dan Bisnis Islam, Vol. 5, No. 1, Januari-Juni 2019

2008-2012. Jurnal IImu Manajemen (JIM), 2(3).

Website Biro Pusat Statistik Republik Indonesia, Pengertian Pendapatan Nasional. (Online). (https://www.bps.go.id/subject/11/produk-domestik-bruto--lapanganusaha-.html) 